\title{
Towards a Conceptual Framework for the Conservation of Urban Heritage
}

\author{
Harsha Munasinghe
}

Men come together in the city, Aristole wrote, in order to live. They remain a group in order to lead a good life. The ordered system of meanings and symbols in terms of social interaction evolved by individuals as members of a group is called culture ${ }^{\prime}$. Their dwelling in urban space, by encoding and decoding meanings according to the norms dictated by their cultural values, gives the city its raison d'etre, that in turn gives orientation and identity to societies in space and time. This evolved essence of the urban space, enhancing Man's knowledge of Man, accrues a heritage value by documenting a transformation of a culture, and its protection secures a cultural continuity ${ }^{2}$. Ever since the concept of time was known, symbols of the past were appreciated for reinforcing a cultural continuity. This past proclaimed by mythology, ideology, nationalism, local pride, or romantic ideas, is the heritage ${ }^{3}$. . The particular way of proclaiming a heritage by ascribing diverse values on it moulded each culture with a unique identity. Among the values ascribing on heritage moulded each culture with a unique identity. Among the values ascribed on heritage are documentary, historic,

\footnotetext{
1 This learned behavior as members of a group on contrary to the genetically- endowed one is understood by the anthropologists as culture. Also Refer Greetz (1973) - The Interpretation of Cultures, New York .,

2 Jokilehto, J. (1986) - "A History of Architectural Conservation", Unpublished D. Phil. Thesis, IoAAS, University of York., presents an excellent historic analysis of architectural conservation.

3 Schouten, F.F.J. (1995) - 'Heritage as Historical Reality' , in Herbert, D.T. (ed) Heritage, Tourism and Society. London
}

nationalistic, aesthetic, religious, age, memorial, cultural, use, and market values, and they are given emphasis according to the contemporary cultural consciousness in order to place the protected heritage within the evolving value system.

As such, the protection of cultural heritage, that is a moral duty of each cultured man, demands to be framed within the concept of heritage, the concept of value, and the concept of dwelling. The evolution of the concept of heritage is twofold; it proclaims the 'entire corpus of material signs of a culture' rather than a few monumental cases ${ }^{4}$, and it is jointly owned by a wider community not an inheritance of a privileged class and more. This, diluting of the concept of heritage from easily identifiable objects to evidence of a culture, has sometimes caused a supplanting of tangible values by diffuse ones, limiting protection actions of urban heritage by placing priorities with nationalistic or religious values, in which the urban setting is reduced into a setting of a monument that derives a significance largely by being placed in it ${ }^{5}$. It has also

\footnotetext{
${ }^{4}$ If this definition given in the UNESCO - "Operational Guidelines for the implementation of the World Heritage Convention". Intergovernmental Committee for the Protection of World Cultural and Natural Heritage, 1998., is compared with William Morris, The Collected Letters of William Morris. (1848 -1880). Vol. I., New Jersey., the evolution of the concept of heritage could be noted.
}

5 Refer Cesari, C. (1989) - "The Conservation and Rehabilitation Process in Italy", for an excellent crosssection of the Italian case. 
forced to identify and present a signified unity of an urban setting. This evolution pattern has not been contributory in appropriating evaluation tools to asses the urban heritage, simply because it is dominated by reactions to contemporary issues such as the destruction during World War II or making of Nation states, and failure to define urban heritage along with the life generated in urban space. Today, conservationists identify a signified unity of a geographically-. delimited urban area, a walled quarter, a street, etc., delineate it with architectural or historical criteria, and protect this unity by placing priorities with the physical fabric at the expense of true heritage values $^{6}$. As a result, the evolution of the cultural patterns are being neglected. The erosion of life in protected urban settings shows how detrimental this has been ${ }^{7}$. Urban, being an environmental quality reflected by the way of life, rather than demographic intensity or activities ${ }^{8}$, urban heritage is an inheritance of a particular evolution pattern of an urban culture?.

6

Conzen , M.R.G (1988) - 'Morphogengensis, morphological regions and secular human agency in the historic townscape, as exemplified by Ludlow' , in Denise and Shaw (eds.) (1988) -Urban Historical Geography. Cambridge

${ }^{7}$ Benevelo, L. \& Cervellati, P. L (1976) -'Conservation of Historic City Centres and Urban planning' in Italian participation at the Habitat conference Rome., and Petherick , Ann and Fraser, Ross (1992) _ Living over the Shop: A Handbook for practitioners, York., are material witness for the degradation of life in the conserved' cities,

${ }^{8}$ Wirth, Louis (1938) - ' Urbanism as a Way of Life', in American Journal of Sociology, 44(9)

9 Faulkner, P.A. (1978) -- 'A Philosophy for the Preservation of our Historic Heritage' , in Journal of the Royal Society of Arts, $126(5,264)$., divides heritage in to two as heritage of ideas and heritage of objects, and shows how intricate the concept of heritage is.
The concept of value, that is well developed in teleological and deontological ethics, helps to categorize the intangible values that are attached to the heritage into two as intrinsic and inherent ${ }^{10}$. Age value, historic value, and architectural value are examples for intrinsic values whereas cultural significance, and historic importance are examples for the inherent values. The externally - enforced values such as tourist or market values cannot be discussed within these two categories. Thus it is necessary to introduce a third, the extrinsic value. It is a fact that these terms are discussed differently by philosophers, some even promoting 'merit' instead of value. As a common tendency, they define the intrinsic value as the one that lies independent of the value, that is supervinient on being a moral subject, could remind a moral duty to protect a heritage. While intrinsic values address emotions and intellects independently, the extrinsic values promote a destruction of heritage. An urban setting, being a heterogeneous - homogeneity "', possesses diverse values. Hence, a proper evaluation of these values in order to prioritize them should be able to support rendering a true protection.

By ascribing inherent values, the duties to protect a heritage can be promoted either as norms or paradigmatic expanse, Inherent value is not the good of moral norms, such as duties of respect, that are binding on moral agents in their relations to non human moral subjects. It is the opposite, because moral agents are bound by moral norms in relation to moral subjects, that have a moral status and a moral status value which may be called inherent values. Since the norms and values determine

\footnotetext{
${ }^{10}$ Taylor , P.W. (1986) - Respect for Nature: A theory of Environmental Ethics. Princeton

11 The international community has begun to discuss the essential role played by the values in environment, but their discussion has so far been limited to description of them. World Commission on Culture and Development (1995) - Our Creative Diversity, Paris., and Lincourt, M. (1996) - "Urban Design Guidelines for the Rehabilitation of Historic Cities", A working paper for UNESCO
} 
the identity of a culture, ascription of inherent values is the most appropriate in terms of facilitating a cultural continuity by placing a proclaimed heritage within the context. On the contrary, the intrinsic value, that is derived from the object independent of the context, gives rise to undue attention and misinterpretation of the heritage.

The concept of dwelling has attracted the attention of conservationists, who note conservation as a way of giving bearings to the living societies ${ }^{12}$. Yet, their attempts are often based on architectural or historic criteria rather than accommodating perception and reaction of everyday users of the setting, thus hardly orientated to identify the way of conceiving a setting by the everyday users ${ }^{13}$. The reciprocal relationship between the society and the setting can be noted by carefully mapping the particular pattern of place-making . If this is enhanced by protecting physical attributes, activities, and concepts $^{14}$, the setting would be protected for cultural values.

Phenomenologists consider that 'place' positions Man in such a way that it reveals the external bonds of a persons existence and the depth of his/her freedom and reality at the same time ${ }^{15}$. As such phenomenological values are the most culturally -significant values of urban space, that is often a non-

\footnotetext{
12. Ralph, E. (1976) - Place and Placelessness, London., has gone beyond the plain discussion to establish that conservation of environmental settings is able to enable place - making.

13 Hubard, Philip (1993) - 'The value of conservation', in Town Planning Review, 64

14 According to Canter, D. (1977) - The Psychology of Place. London., These are the three major constituents of place. The author wishes to take. this further to investigation their collective impact on place-making rather than places themselves.
}

15 . Heidegger, Martin (1958) - “ An Ontological consideration of place", in The Question of Being, New York celebrated history or a non-intentional monument ${ }^{16}$. Because they document the particular dwelling patterns of the life lived, thus the cultural patterns evolved in it. Once the place - making by different sub- cultural groups should be respected, the diversity of urban heritage would also be protected thus reinforcing its capacity in supporting a cultural continuity. Dwelling is paid least attention by architects, who are busy with creating master -pieces for themselves, and it has been continuously neglected by the conservationists who are largely architects. The essential task of an architect is enabling the place - making in the sense of endowing a considerable part of the human environment with a special order $^{17}$, and the essential task of a conservationist would thus be to ascribe the space with inherent values that facilitate placemaking ${ }^{18}$.

The word conservation is popular in many contexts. Its widest ramification promotes a management of an object that is in the process of aging or transmission. Yet, conservation is commonly understood as saving. With the rise of architectural and urban conservation after the World War Two, it is understood as preserving and presenting a history. These should be replaced by emphasizing its capacity to promote the appropriate use of resources in time and space, rather than petrifying expressive elements such as built forms or facades or surface materials. The conserved heritage is a joint product of yesterday and today, and it is intended for a

\footnotetext{
${ }^{16}$ Reigl, Alois (1903) - ' Modern cult of monument: Its Character and Its Origin', in Kurt W. Foster and Daine Ghirardo (eds.) Oppositions: A Journal in Ideas and Criticism in Architecture, New York: Rizzoli, Fall 1982 (translation of ' DerModerne Denkmalkultus, sein Wesen, Sein Entstehung')

17 Norberg- Schulz, (1985) - The Concept of Dwelling : On the way to Figurative Architecture New York : Rizzoli, Fall, 1982 (translation of 'Der Moderne Denkmalkultus, sein Wesen, Sein Entstehung ')

18 Tuan, Yi-fu (1977) - Space and Place: The perspective of Experience. Minneapolis
} 
better tomorrow. As such, conservation is more an investment than a saving.

The conservation approach practiced globally can be categorized in to three types ${ }^{19}$. They are the traditional approach that aims at preserving the use values, the romantic approach, that evolved with romanticism and nationalistic ideas during the Italian Renaissance, and the historic approach that developed with an emphasis over the documentary values and authenticity. John Ruskin and William Morris could be considered as the pioneers of this third approach which blossomed after the World War II. These approaches are based on intrinsic values, and promote extrinsic values thus endangering a cultural heritage by fencing off from the context, by prioritizing a physical fabric, by drawing undue attention or by making the past superior to the present. As a whole, they have failed to enrich a culture or make the society intelligible. Keeping the history in exhibition to look at has also promoted its neglect ${ }^{20}$.

19 Jokilehto, J. (1988) - ' Conservation Principles and Theoretical Backgrounds', in Durability of Building Materials 5. Amsterdam., describes the three approaches convincingly.

\footnotetext{
20 Marcuse , Peter (1974) - ' Conservation for whom ?', in J.N. SMITH (ed.) Environmental Quality and Social Justice in Urban America . Washington DC., analyses the case of Williamsburg, Virginia where one historic moment is frozen as a tourist -object.
}

Protecting documentary values for the sake of creating a historic consciousness does not necessarily support a cultural continuity as the proclaimed heritage could also symbolize a repressed past, or neglected the current cultural consciousness. In the multi- cultural settings such as post colonial cities, none of them can protect the values of an urban heritage. There is a demand for a fourth approach, that assesses all merits of heritage as a whole, and protects it by ascribing inherent values. This threefold approach; first evaluating values, second appropriating actions, and third ascribing inherent values, embraces the particular evolution patterns of the environmental quality that supports the place - making capacity.

Thus identifying the evolved urban quality as the basis for intervention could promote the living communities as the true guardians who realize the protection at site. By recognizing their living as essential for the enrichment of the heritage value of urban space, or in short once conservation values are derived within the present cultural consciousness, a true protection could be rendered. By bringing cultural values to the centre of decision making with regards to development, conservation of urban heritage could be promoted as the vehicle of realizing a promising future.

Harsha Munasinghe holds a PhD from the University of Oulu in Finland and is a Post Doctoral Researcher there. He also works as a reserach consultant at the city of Helsinki- Urban Facts. He is a visiting lecturer at the Helsinki University of Technology. 